SSN 2663-0575 (Print)

ISSN 2663-0583 (Online)

Access to Justice in Eastern Europe,

Issue 2/3 (7) 2020

http://ajee-journal.com

10.33327/AJEE-18-3.2-3

B Szolc-Nartowski 'Coronavirus and the Justice System in Poland' (2020) 2/3 (7) Access to Justice in Eastern Europe 172-175.

10.33327/AJEE-18-3.2-3-n000034

\title{
CORONAVIRUS AND THE JUSTICE SYSTEM IN POLAND*
}

\section{Szolc-Nartowski Bartosz \\ PhD (Law), Assoc. Prof., University of Gdansk, Poland}

Summary: 1. Introduction. - 2. Organizational measures. - 3. Conclusion.

The justice system was unprepared for the dangers of the Coronavirus pandemic, both in Poland and everywhere in the world. However, the need for safeguarding fundamental civil rights, such as human life and health, has always been the highest priority. In this note the measures aimed to protect every during the pandemic in Poland were studied and concluding remarks to be learned were proposed.

Key words: COVID-19, civil justice, judiciary, oral hearings, procedural time-limits.

\section{INTRODUCTION.}

While free access to the courts is, indeed, an essential and self-contained legal construct, it is not an end in itself. In fact, being a constitutionally guaranteed procedural right, it is

Received: 04.09.2020. Revised: 06.09.2020. Approved: 08.09.2020

(c) 2020 Access to Justice in Eastern Europe and Bartosz Szolc-Nartowski.

This work is licensed under a CC BY NC ND 4.0 license.

This is an Open Access publication distributed under the terms of the Creative Commons Attribution 4.0 International License, which permits to copy and distribute the material in any medium or format in unadapted form only, for noncommercial purposes only, and only as long as attribution is given to the creator. 
accessory to other fundamental freedoms set out in the Polish constitution and statutory law. Restricting the right to free access to the courts strikes at the members of society and their fundamental rights, especially where scope exists for exercising this right in a COVID-safe manner. There is no doubt that solutions created under time pressure will have imperfections. Also, the maintenance of the continuity of judicial functions, while working at the same time to ensure safety to all those who spend time in court buildings (litigants, witnesses, forensic experts, attorneys, judges, and administrative staff), was definitely a daunting task.

\section{ORGANIZATIONAL MEASURES}

Safety procedures and organizational measures were enacted by order of the presidents of courts, by recommendations of the Ministry of Justice, and by subsequent statutory legislation.

As of 12 March 2020, presidents of courts issued orders to cancel all docketed court hearings and sessions, provide all interested parties with appropriate notifications, and to the extent possible reschedule the cancelled hearings and sessions. A number of measures were enacted to restrict the flow of information internally within the courts, for example, access to the files reading room was allowed only for urgent cases or cases in which an appealable judgment has been passed. Customer service offices were closed, followed by the closure of the court office and cash desks.

The Ministry of Justice provided the Presidents of the Appeals and Regional Courts with a list of urgent cases, instructing them to exclude these particular cases from the cancellation order. Urgent case status was decided by the values and interests at issue in the case (human life and health, freedom, protection of the most vulnerable). The presidents of courts could make further discretionary exemptions from the cancellation order for cases that needed to be examined. The Ministry of Justice requested all common courts of law in Poland to post information on the categories of urgent cases on the websites.

The legal basis for the issued instructions was the Law on the System of Common Courts and the Act on Preventing and Combating Infections and Infectious Diseases in Humans.

Although assurances were made by the presidents of courts that correspondence could be exchanged by e-mail, with the assumption that any formal defects in the pleadings could be supplemented at a later date, the courts themselves, the parties and their attorneys continued to exchange letters by post in fear of adverse procedural consequences. This meant that attorneys had to visit post offices and experience the stress of being exposed to the possibility of infection. This showed the full extent of deficiencies in the digitization process of judicial procedure. The courts soon purchased special UV-C sterilization lamps, which were used to disinfect the submitted pleadings. The presidents of courts issued orders to suspend the service of all court papers relating to means of legal recourse and procedural time-limits, with the exception of urgent and executory cases. 
At the same time, it became possible to cancel hearings in urgent case where a large number of persons were summoned to appear at trial. Distancing measures were also applied by restricting admission to court buildings to persons who could show a summons, a notice to appear in court or a published judgment. Petitioners were strongly encouraged to contact the court by phone or e-mail. To meet procedural time-limits, it was recommended to deliver court letters by e-mail and have them printed in the court office. The missing signature of the petitioner or attorney could be added at a later day.

The question of the expiry of procedural time-limits was finally decided by the legislature under the Act on Special Solutions Related to the Preventing, Counteracting and Combating COVID-19, Other Infectious Diseases and Associated Emergencies of 2 March, 2020. Under Article 15zzs of the Act, the running of procedural and litigation time-limits shall not start, and where it has started, it shall be suspended for the duration of the epidemiological hazard or the state of epidemic declared due to COVID. The regulation applied to court proceedings, including administrative court proceedings, executory proceedings, penal proceedings, penal tax law proceedings, and cases relating to misdemeanours, administration and administrative enforcement.

The Act also specified solutions regarding the possibility of designating an equivalent substitute court of venue in urgent cases falling within the competence of the court, whose work has been suspended, with the aim of safeguarding the right of free access to the courts, within the organizational capacity of courts. Presidents of courts were also given authority to hear each case as urgent, where failure give a hearing would endanger the life or health of a human being or animal, cause severe harm to community life or irreparable material damage, or - under a subsequent general clause - where this is required to serve the vital interests of the justice system. Provision was made to delegate judges to other courts due to concern for the vital interests of the judiciary.

It should be stressed that the staying/suspending order applied only to procedural and litigation time-limits, not to proceedings themselves. Where proceedings are in progress, both the court and the parties can effectively perform procedural acts.

14 May 2020 saw the adoption of legislation to safely 'unfreeze' courts, effective as of 16 May 2020; Article 15 zzs was repealed, a seven-day waiting period was adopted, on whose expiry the stopped time-limits would start running, while the suspended timelimits would continue running. As a consequence, the commencement of the running of stopped time-limits and the continuation of the running of suspended time-limits took effect as of 24 May 2020 under Article 15zzs of the Act.

All court proceedings open to the general public may again be held on condition that they do not excessively endanger the life or health of the participants. At the same time, Art. $15 \mathrm{zzs}^{1}$ was added to make provision for remote hearings by technical means enabling simultaneous transmission of image and sound (video-trial). However, no regulations were enacted to set down standards with regard to video-trials. The specific issues concerned include confidential and secure data transfer, streaming, access to case records and files, identity checks, simultaneous recording of all participants.

The justice system was also given the discretion to conduct proceedings behind closed doors where this was deemed to be necessary by the court and where conducting 
the legally mandatory proceeding at trial or hearing would unnecessarily endanger the participating persons, or where utilizing remote methods with the simultaneous transmission of image and sound is not feasible. The parties could raise objections within a period of seven days from the date of service of notice indicating the court's intention to hold the proceeding in camera.

Another solution was to allow the members of the bench to participate in the proceedings by electronic means of communication. This right was not extended to the presiding judge and the reporting judge. The above persons may avail themselves of the right only in special circumstances but never during the closing session.

These extraordinary measures in civil procedure will remain in force for a year counting from the end of the state of the state of epidemic. This solution may raise legitimate doubts: extraordinary measures should not have permanent effects and the period should be shortened.

The Act also introduces a special limitation on the principle of openness of proceedings in recognition that if the evidence proceedings have been completed, the court may close the case and pass judgment in a session behind closed doors, having received from the parties or other participants their statements in writing.

Also, presidents of courts issued further orders to limit the working hours. Access to court buildings was granted to those who had a legitimate reason to be there, i.e. summons to appear at trial, appointment to peruse case files in the reading room, or who wished to file a complaint with the head of division or president. In order to ensure the openness of court proceedings but also out of concern for safety, access to the courtroom was granted to members of the general public by permission of the presiding judge where this did not pose an excessive health risk to those present. Court offices were opened. 'Drop boxes' were posted near the buildings where submissions could be made without the need to enter the building or send letters. Tightened safety measures are in force till today.

\section{CONCLUDING REMARKS.}

The legislative and organizational measures applied during the Coronavirus pandemic must be compatible with the right of access to the courts. This right is a component of the principle of a state under rule of law. The Constitution of Poland defines these components as the fundamental pillars upon which the rights and freedoms of the individual rest, and which safeguard these rights and freedoms. The present health crisis has revealed the weak points of the justice system, its methods of operation being still very much rooted in the $19^{\text {th }}$ century. The crisis has shown the urgency of the need for appropriate legal, organizational and infrastructural measures to digitize and streamline communication. At the same time, we have acknowledged the potential of the judicial community that has shown the initiative to take action to protect the citizens and their fundamental rights. 